\title{
Understanding Landscape Use Patterns of Livestock as a Consequence of Foraging Behavior
}

\author{
Karen L. Launchbaugh ${ }^{1}$ and Larry D. Howery ${ }^{2}$ \\ Authors are ${ }^{1}$ Associate Professor, Rangeland Ecology and Management Department, University of Idaho, \\ Moscow, ID 83844; and ${ }^{2}$ Associate Professor, School of Renewable Natural Resources, Rangeland and Forest Resources Program, \\ University of Arizona, Tucson, AZ 85721.
}

\begin{abstract}
Many grazing-management challenges stem from poor livestock distribution resulting in overuse of some areas and low utilization of others. Managing livestock-distribution patterns requires knowledge of pasture characteristics and animal behavior patterns. Behavioral patterns result from recognizable processes that include inherited attributes, individual and social learning systems, cue-consequence specificity, predispositions toward novel stimuli, and spatial memory. Through these behavioral mechanisms, animals form and revise preferences and aversions for specific locations in their foraging landscape. To accomplish habitat selection, domestic herbivores use sight and sound cues to seek and return to high-quality foraging locations. Nested within habitat selection are learned diet preferences and aversions by which ungulate herbivores associate taste with positive or negative postingestive feedback. The deliberate and careful modification of animal attributes and habitat characteristics could yield options for adaptive rangeland management. In this article, we describe the basic principles that underlie how animals make decisions about where to forage and how long to stay in a particular habitat. We also suggest management practices designed to modify animal behavior and alter habitat-use patterns.
\end{abstract}

\section{Resumen}

Muchos de los retos en el manejo de apacentamiento tienen su origen en la pobre distribución del ganado que resulta en la sobreutilización de algunas áreas y la subutilización de otras. El manejo de los patrones de distribución del ganado requiere del conocimiento de las propiedades del potrero y los patrones de comportamiento del ganado. Los patrones de comportamiento resultan de procesos reconocibles que incluyen atributos heredados, sistemas de aprendizaje individuales y sociales, especificidad de consecuencias, predisposición hacia un estímulo novedoso y la memoria espacial. A través de estos mecanismos de comportamiento, los animales forman y revisan las preferencias y aversiones para localidades especificas en el paisaje donde apacientan. Para lograr la selección del hábitat, los herbívoros domésticos usan señales visuales y de sonidos para buscar y regresar a localidades de apacentamiento de alta calidad. Incluidas dentro de la selección del hábitat están las preferencias de la dieta y aversiones aprendidas, mediante las cuales los herbívoros ungulados asocian el sabor con una retroalimentación post-ingestiva negativa o positiva. La modificación deliberada y cuidadosa de los atributos animal y las características del hábitat pudiera producir opciones para el manejo adaptativo del pastizal. En este artículo describimos los principios básicos que determinan como los animales toman decisiones acerca de donde apacentar y cuanto permanecer en un hábitat particular. También sugerimos prácticas de manejo diseñadas para modificar el comportamiento animal y alterar los patrones de uso del hábitat.

Key Words: habitat preferences, habitat selection, livestock distribution, place aversions, place preferences, spatial memory

\section{INTRODUCTION}

Grazing is an ecological force that humans have been trying to control since animals were domesticated 10000 years ago and the era of livestock management was born (Walker 1995). We have made good progress toward understanding plant response to grazing and creating guidelines and systems to manage the impacts of grazing and promote livestock production. Even in

This synthesis was presented as part of the "Livestock Grazing Distribution" Symposium at the 56th Annual Meeting of the Society for Range Management held in Casper, Wyoming. Manuscript made possible by USDA-CSREES funding for a program called BEHAVE (more information at www.behave.net).

Correspondence: Karen L. Launchbaugh, Rangeland Ecology and Management, University of Idaho, Moscow, ID 83844-1135. Email: klaunchb@uidaho.edu

Manuscript received 24 March 2003; manuscript accepted 1 June 2004. managed situations, selective foraging is important because it can profoundly influence plant community structure and function (Pieper 1994; Jones 2000). Selective foraging patterns can result in overgrazing of preferred areas while other areas receive little grazing attention (Walker 1995; Bailey and Sims 1998). Therefore, a major challenge for range managers is to achieve land-management objectives in light of complex and dynamic patterns of livestock behavior.

Every herbivore is born with a set of behavioral predispositions, physiological systems, and physical attributes that influence their decisions about where to forage, drink, or rest and ruminate. As young herbivores experience their foraging environment, they accumulate knowledge regarding habitat quality and refine their foraging skills. Animals learn about their foraging environment through their own experiences and from other members of their herd or flock. Habitat preferences, therefore, result from complex 


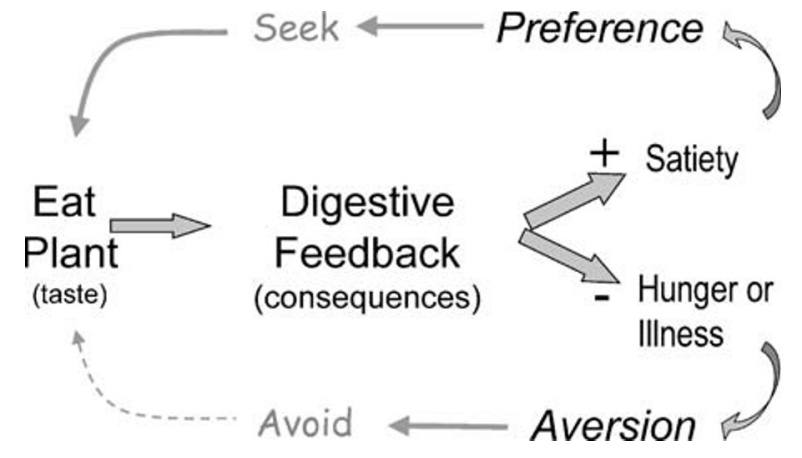

Figure 1. Animals learn preferences or aversions to food based on digestive feedback. The digestive feedback serves to alter the hedonic value (either favorable or aversive) of the plant and is observed as a behavioral response by the animal to avoid eating the plant in future encounters or to seek and eat the plant when encountered.

and ongoing interactions between genetic and environmental factors that influence foraging behavior of individuals and groups. The intertwined actions of inheritance and experience result in adaptive foraging behavior. Though behavioral patterns are often complex and difficult to explain, they stem from a limited number of recognizable and definable ontogenetic mechanisms. These include inherited attributes, individual and social learning systems, cue-consequence specificity, predispositions toward novel stimuli, and spatial memory. The deliberate and careful modification of animal attributes and habitat characteristics could therefore yield options for adaptive rangeland management. In this paper, we will describe the basic principles that underlie how animals make decisions about where to forage and how long to stay in a particular habitat. We will also suggest management practices designed to modify animal behavior and alter habitat-use patterns.

\section{INHERITANCE AND EXPERIENCE}

Herbivores possess skills, abilities, and knowledge that guide foraging decisions and set boundaries on potential behavioral responses. To effectively forage, animals must possess abilities to detect the presence and quality of food, locomotion to travel and harvest forage, and memory to store locations of forage and water sources. While on a mission to satisfy their nutritional needs, animals must also be able to recognize and remember places and situations that are dangerous or offer few resources. Behavioral systems for foraging must integrate abilities and memories in a way that is adaptive in a constantly changing environment (Provenza and Balph 1990).

Habitat-use patterns result from operant and classical conditioning procedures. Each individual behaves uniquely because interactions with its environment shape its behavior, beginning at conception and continuing unceasingly until death. Natural foraging environments are complex and chaotic, yet many events occur in rather predictable patterns. Animals can learn to associate cues that foreshadow important events through learning procedures called Pavlovian or classical conditioning initially outlined by Ivan Pavlov (Pavlov 1927; McSweeney 1999; Frieman 2002). Animals can learn to associate habitat cues that predict the occurrence of positive consequences (i.e., forage, cover, safety) to increase the chances of obtaining these resources. Alternatively, the recognition of cues that warn of negative outcomes can allow animals to avoid dangerous or deficient habitats (Frieman 2002). Animals also learn appropriate foraging behavior based on the consequences of their actions. When a behavior results in positive consequences, it increases the likelihood of the behavior being expressed in the future, whereas aversive consequences decrease the future likelihood of the behavior. This consequent-based learning was most prominently advanced by B. F. Skinner and is called operant conditioning (Skinner 1938; McSweeney 1999; Frieman 2002). When applied to habitat selection, operant conditioning predicts that animals would seek, select, and reside in habitats that contain positive attributes, such as abundant, high quality forage, water, or comfortable thermal regimes. Conversely, animals would avoid habitats that do not provide adequate positive reinforcement or those that contain aversive elements, such as poisonous plants, predators, or insect pests.

It may not be necessary for herbivores to inherit a strong picture of appropriate or optimal habitat. Rather, animals may inherit an ability to learn about the habitat in which they live (Launchbaugh et al. 1999; Frieman 2002). Herbivores are born with the ability to sense habitat features by seeing, hearing, smelling, and tasting. Foraging animals are instinctively able to relate these habitat features to the benefits (e.g., nutrient intake, thermal comfort, water sources, etc.) or hazards (e.g., predators, steep terrain, inadequate nutrient sources, excessive temperatures, etc.) presented by a specific habitat. Furthermore, herbivores are born with the ability to remember where resources might be sought or hazards avoided (Bailey et al. 1996). Learning provides animals with the ability to adapt quickly and appropriately to the constantly changing environments in which they live (Provenza and Cincotta 1993; Provenza and Launchbaugh 1999).

\section{FORAGING DECISIONS BASED ON FOOD PREFERENCES AND AVERSIONS}

Herbivores select thousands of bites each day in a way that generally allows them to acquire sufficient nutrients and avoid consuming lethal doses of phytotoxins (Provenza et al. 1992; Provenza 1995). Studies of landscape-use patterns and animal distribution have widely confirmed that domestic and native grazing herbivores select and spend more time in plant communities that offer abundant quantities of preferred forages (reviewed by Senft et al. 1987; Illius and Gordon 1993). Therefore, spatial foraging decisions are strongly influenced by dietary preferences (Bailey et al. 1996). Provenza and colleagues (1992) outlined a system of forage preferences and aversions by which seeking or avoiding specific plants is based on the postingestive consequences of eating the plant. By this widely tested model (Provenza 1995, 1996), herbivores eat and taste a plant and, if its consumption is followed by nutritional benefit, preference for the plant increases and the animal will seek and consume the plant in future encounters (Fig. 1). Alternatively, if consumption is followed by internal malaise, illness, or continued hunger, the plant becomes distasteful and animals will avoid it when encountered in the future (Fig. 1). The key result of these flavor-consequence relationships is 
that the hedonic value of flavor is modified by postingestive consequences. For example, when lambs (Ovis aries) experienced nausea after eating a meal of cinnamon-flavored rice, they subsequently avoided cinnamon rice and other cinnamon-flavored feeds (Launchbaugh and Provenza 1993). The flavor of cinnamon was preferred before, but avoided after, lambs experienced nausea. Hence, animals experienced a negative hedonic shift for the flavor of cinnamon.

\section{SKIN AND GUT DEFENSE SYSTEMS INFLUENCE HABITAT SELECTION}

In addition to digestive feedback, there are many other habitat attributes that apparently guide animal decisions to seek or avoid specific habitats. Garcia and colleagues (1985) proposed that animals possess 2 fundamentally different systems to protect themselves from hazards to their external and internal environments (Garcia et al. 1985; Garcia and Holder 1985). The skindefense system protects animals from hazards in the external environment (e.g., electric shock, predators), while the gutdefense system protects animals from hazards to the internal environment (e.g., poisons, toxins in foods). As a consequence of these 2 systems, laboratory rats (Rattus norvegicus) more easily associate audiovisual cues with electric shock and taste stimuli with gastrointestinal illness. This phenomenon is known as cueconsequence specificity. Garcia and Koelling (1966) found that rats avoided the place where they ate a particular food, but not the food, when the place was associated with electrical shock. Conversely, when the food's ingestion resulted in nausea, rats avoided the food but not the place where they ate the food.

Domestic ungulates are also affected by cue-consequence specificity. Livestock readily learn to avoid places associated with electric shock administered from shock collars or electric fences. They also learn to avoid foods that contain toxins, presumably on the basis of aversive postingestive feedback through the gut-defense system. Hereford steers (Bos taurus) were trained to avoid a designated aversion area in less than 2 days by using remotely controlled audioelectrical stimulation (Quigley et al. 1990). By day 4, the audio signal alone was sufficient to keep the steers out of the target area. Goats (Capra hircus) equipped with electric shock collars learned within 30 minutes to remain inside a designated area (Fay et al. 1989). Noncollared goats remained close to collared goats and also remained in the designated area, indicating that a desirable behavior exhibited by a few individuals could be socially transmitted into a larger group of animals. More recently, virtual pastures of various shapes and sizes have been created to confine livestock to a particular area by combining geographic positioning system technology with electrical-shock collars (Anderson 2001). Understanding the skin- and gut-defense systems may provide promising new ways to manipulate herbivore use of plants and habitats from the bite to the landscape.

\section{HABITAT PREFERENCES AND AVERSIONS}

Herbivores prefer and select some habitats over others. Just as animals form preferences or aversion for foods based on consequences of consumption, they form likes and dislikes for

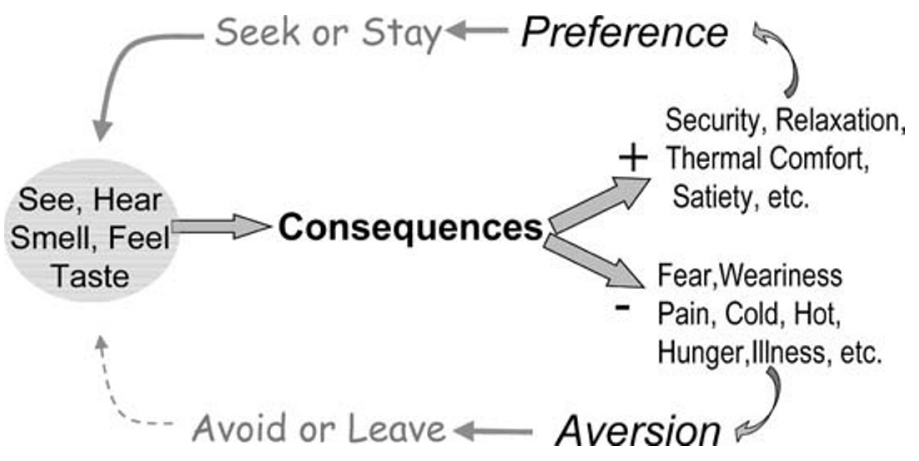

Figure 2. Aversions or preferences for places and habitats are created when the animal associates sensory stimuli (i.e. sight, sound, odor, taste, or feel) with the consequences of residing in the habitat. If the consequences are positive (i.e., satiety, thermal comfort, etc.), place or habitat preferences result. If the consequences are aversive (i.e., pain, hunger, illness, etc.) then place or habitat aversions are formed.

places or habitats based on consequences. Locations that provide food, water, warmth, or drug-stimulated euphoria are preferred over those that offer no positive reinforcement (see reviews by Carr et al. 1989; Parker 1992; Tzschentke 1998; Schechter and Calcagnetti 1998). Conditioned preferences have also been demonstrated for places that harbor positive social interactions, such as play among juvenile animals, opportunities for sexual interactions, successful aggressive interactions among males, and presence of offspring for mothers (see Tzschentke 1998). Habitat preferences are also likely formed to places that provide escape from fear (such as that caused by predators), pain (such as that induced by electric shock or insect pests), stress, hunger, and excessive heat or cold (see Schechter and Calcagnetti 1998). Conversely, animals form aversions to places that possess aversive stimuli, such as pain, excessive heat, or nausea (Tzschentke 1998; Cibils et al. 2004).

The vast majority of research on the formation and persistence of conditioned place preferences was accomplished with laboratory rats (Schechter and Calcagnetti 1998). However, a model for place preferences or aversions in free-ranging livestock and wildlife undoubtedly follows the same basic pattern. The formation of conditioned preferences or aversions would begin when an animal sees, hears, smells, or feels habitat characteristics that could include forage attributes, topographic features, temperature, wind, manmade structures, or other animals (e.g., conspecifics, predators, insects, or humans; Fig. 2). A preference would be formed for habitats that resulted in satiety, relief of thirst, thermal neutrality, freedom from pain, comfort, a sense of security, or rest. Aversions would predictably be formed for habitats in which the animal experiences hunger, excessive heat or cold, pain, stress, illness, weariness, or fear (Fig. 2). For example, it is widely recognized that animals can become averted to handling facilities if the movement through these facilities is associated with pain and fear (Grandin and Deesing 1998). Alternatively, animals can form place preferences and easily move through handling facilities associated with a food reward (Hutson 1981).

Grazing animals simultaneously experience many consequences of being in a habitat and the habitat's hedonic value changes based on these positive or negative consequences. Habitat preferences are observed when animals seek and stay 
in a specific habitat. Habitat aversions are inferred when an animal leaves or avoids poor habitats. Thus, habitat selection is an inherently multivariate process where a set of habitat cues is related to a set of consequences that modifies the habitat's hedonic value (Fig. 2).

\section{EXPLORATION, SEARCHING, AND RESPONSE TO NOVELTY}

When livestock are introduced into a new pen, pasture, or allotment, their behavioral response depends on their early life experiences and the presence of peers. Sudden and intense sights, sounds, and odors are generally aversive to animals and provoke fear responses (Boissy 1998; Nolte 1999). Conditioned aversions can be created for places that include sudden novelty such as loud, unfamiliar sounds (Tzschentke 1998). Animals raised in complex environments that regularly contain novel stimuli express less fear and anxiety when confronted with a sudden novel event than animals with early life experiences in simple and predictable environments (e.g., pens in confinement; Boissy 1998). Novel situations will often be less aversive when experienced with peers than when experienced alone, constituting an effect known as social buffering (Epley 1974). Domestic cattle (Veissier and Le Neindre 1992) and sheep (Vandenheede and Bouissou 1994) were less disturbed by novel stimuli when exposed with peers than when exposed alone. However, the presence of peers can also heighten stress and fear if the companions express fear in response to a novel stimulus (Boissy 1998).

An example of using novel stimuli to change landscape-use patterns is the use of frightening devices such as bright lights, explosions, and loud sounds to reduce wildlife depredation of valuable agronomic or horticultural resources (Nolte 1999). When first encountered, wildlife will tend to avoid areas guarded by frightening devices. However, wildlife quickly becomes acclimated to the novel stimulus and it loses its effect within a few days or weeks unless it is followed by negative consequences such as pain (Nolte 1999). For example, elk (Cervus elaphus) on golf courses readily habituate to pyrotechnic devices, but when rubber balls in combination with the pyrotechnic display occasionally strike them, they quickly leave the fairway. Novel fear-inducing devices can alter habitat-use patterns more easily when animals are just starting to explore new habitats. Well-established use patterns are difficult to alter with intense novel stimuli (Nolte 1999).

Physiological or nutritional state can influence responses to novelty. When nutritional and physiological conditions are adequate, animals prefer familiar foods and places to novel ones (i.e., animals are neophobic). For example, when lambs (O. aries) on an adequate diet were introduced to a new foraging environment, they more readily consumed a familiar food than novel ones, even though the familiar food was aversive in previous situations (Burritt and Provenza 1997). When nutritional and physiological conditions are inadequate, animals avoid familiar foods and places in favor of novel ones (i.e., animals are neophyllic). As habitat resources become inadequate, animals will often range more extensively and explore new habitats. For example, cattle (B. taurus) and sheep (O. aries) graze over larger areas in the late dry season than in the early- and mid-wet seasons, when forage is abundant and of high nutritional quality (Dudzinski et al. 1978, 1982; Howery et al. 1996). The tendency to explore novel food options could reveal new nutritional resources during times of scarcity. Exploration may be worth the risk to animals that are nutritionally deficient but not to animals that are meeting their nutritional needs.

Domestic and native rangeland herbivores are often described as engaging in exploration and investigation (Hafez 1969). When animals are introduced into a new pen or pasture, whether or not they engage in exploration depends on novelty, internal state, and presence of companions. Animals are likely to explore a new environment if it is similar to a familiar area, animals are mildly hungry and thirsty, and they are introduced to the pasture with companions. Alternatively, livestock will often stand at the gate where they entered a new pasture if the trip to the new pasture was stressful, the landscape is much different than anything they have experienced in the past, and they have become separated from peers. Thus, novelty can elicit fear or encourage exploration depending on their previous experience and the conditions in which the animals are introduced to the novel place or event (Boissy 1998; Grandin and Deesing 1998).

\section{ANIMAL ATTRIBUTES THAT AFFECT HABITAT PREFERENCES}

It is clear that animals select foraging habitats that have reinforcing properties and avoid habitats that possess aversive stimuli or lack benefits. An inherent foundation to this principle is that the potential reinforcement or aversive nature of a habitat is largely determined by the morphological and physiological attributes of the animal. Inherited morphophysiological characteristics that might affect the reinforcement potential of a habitat include mouth size, tooth structure, digestive morphology, metabolic abilities, detoxification capacities, etc. (Illius and Gordon 1993; Launchbaugh et al. 1999). For example, if an animal is built to eat grass (e.g., grass/roughage feeders; Hofmann 1989), then when that animal is foraging in a habitat replete with nutritious grass, the habitat will likely be positively reinforcing. That same grassland habitat may not be adequate to meet the needs of a concentrate selector, like white-tailed deer (Odocoileus virginianus; Illius and Gordon 1993). Consequently, the hungry, malnourished feeling the concentrate selector experiences when foraging in grasslands may be punishment and cause the animal to leave a grassland habitat and avoid it in the future.

Animals begin their life of foraging with a set of physical skills that they learn and accomplish with little difficulty (i.e., walking, biting, chewing). Foraging animals use these abilities to seek and exploit habitats that meet their nutritional demands. However, these physical abilities may set limits on the habitats and plants available to the foraging animal (Illius and Gordon 1993). Some habitats may not be usable to herbivores that lack physical abilities to handle steep terrain or travel far from water (Coughenour 1991; Bailey et al. 1996). For example, freeranging Tarentaise cattle (B. taurus) have been observed to graze steeper and more rugged terrain than Hereford cattle ( $B$. taurus), perhaps because of their inherited physical abilities 
(Bailey et al. 2001). Free-ranging cattle of Brahman breeds (Bos indicus; i.e., Brangus and Santa Gertrudis) grazed further from water than British breeds (B. taurus; i.e., Hereford or Angus) in studies on New Mexico rangelands (Herbel and Nelson 1966; Winder et al. 1996).

We know that the foods an animal eats can change the physical and physiological abilities of the animal. For example, goats reared from 1 to 4 months of age with their mothers on blackbrush (Coleogyne ramosissima Torr.)-dominated rangelands ate twice as much blackbrush as goats naive to blackbrush when compared at 4 months of age (Distel and Provenza 1991). These experienced and naive goats differed physiologically (e.g., experienced goats excreted more uronic acid per unit body mass) and morphologically (e.g., experienced goats had larger reticulorumen volume) immediately following exposure. Nine months later, after both groups of goats foraged on blackbrush pasture and animals were offered blackbrush in pens, experienced goats still ate $27 \%$ more blackbrush than naive goats when only blackbrush was offered and ate $30 \%$ more when blackbrush was given as a choice with alfalfa pellets. These experience-induced differences in morphophysiological attributes and diet preferences could affect the specific habitats selected by these goats.

Can foraging experiences improve an animal's physical ability to traverse rough terrain or travel greater distances from water? Habitat-use skills could affect habitat selection. For example, as animals gain the ability to use steep slopes, they may start to prefer these slopes if forage or thermal conditions are favorable. This seems logical and there is anecdotal evidence that it occurs (Budd 1999), but it has not been well studied or documented.

We also know that age and experience can affect landscape use patterns. It is generally believed that young grazing animals travel farther and range more widely than older animals. This pattern has been observed in several studies (Dunn et al. 1988; Howery et al. 1996). However, other studies suggest that mature, experienced cattle can hold habitat affinities that lead to more even distribution on rangeland (Bryant 1982). Experienced, mature cattle are also able to locate and use habitat with superior thermal and forage resources better than younger cattle (Beaver and Olson 1997). Effect of age on habitat-use patterns is difficult to interpret because age and experience are inherently confounded.

\section{SPATIAL MEMORY AND VISUAL CUES INFLUENCE HABITAT SELECTION}

Spatial memory allows free-ranging ungulates to revisit nutrient-rich feeding sites while avoiding sites that contain low nutrient levels (Bailey et al. 1996). Through spatial memory, animals can remember the location, appearance, and odor of particular habitats. Bailey et al. (1996) developed a conceptual model that incorporates spatial memory. Their model predicts that habitat selection is based on an animal's previous experience with abiotic characteristics and forage resources. The model predicts that animals can learn and retain foraging experiences and apply this information to subsequent foraging decisions. Experimental evidence indicates that livestock can remember and seek habitats that produce high-quality forage
(Howery et al. 1996, 1998, 2000) and, conversely, remember and avoid areas with inadequate forage resources (Bailey 1995).

Cattle used spatial memory to relocate food in mazes and arenas without the benefit of overt visual cues (Bailey et al. 1989; Bailey and Sims 1998; Laca 1998). Although cattle apparently have accurate spatial memories, reliance on spatial memory alone on vast grazing allotments would require storing an enormous amount of information. As the number of feeding sites or habitats increases, the accuracy of spatial memory would theoretically decline and adaptation to novel foraging environments would be difficult (Laca 1998).

Howery et al. (2000) suggested visual cues associated with various aspects of natural foraging environments likely enhance the spatial abilities of free-ranging ungulates, allowing them to forage more efficiently in nutritionally diverse landscapes. At finer scales, large herbivores associate visual cues with plants or patches (Bazely and Ensor 1989; Edwards et al. 1997). At larger scales, free-ranging herbivores discriminate among visual cues that are associated with the locations of forage, cover, and water resources, as well as predators and other environmental hazards (Garcia and Koelling 1966). Foraging landscapes often contain a variety of natural (e.g., trees, rock outcrops, mountain ridges, rivers) and man-made cues (e.g., supplement troughs, windmills, fences, or roads) that animals likely learn to associate with preferred (or nonpreferred) foraging locations. Visual cues greatly enhanced the ability of cattle to more efficiently locate and consume foods placed in fixed or variable locations within an experimental pasture (Howery et al. 2000). More research is needed to determine whether manipulating natural and artificial visual cues can be used to address animaldistribution problems under field conditions.

In rangeland situations, spatial memory and visual cues help animals make decisions about where to graze both in the short term (minutes, hours, or days) and long term (weeks, months, or years). The attributes of a habitat must therefore serve a dual role for free-ranging ungulate herbivores: 1 ) the sight of a habitat becomes preferred or avoided depending on consequences in the short-term and 2) the visual attributes of a habitat become location cues that are entered into their long-term memory. On extensive grazing allotments, cattle probably use spatial memory and visual cues to discriminate among plants and patches in the short term and locate preferred feeding sites and habitats in the long term. Thus, spatial memory and visual cues would serve to improve overall foraging efficiency of herbivores across spatial and temporal scales.

\section{SOCIAL LEARNING INFLUENCES HABITAT SELECTION}

Social learning in gregarious ungulates is believed to facilitate transfer of critical information, such as the location of food, water, and cover in foraging environments (Provenza and Balph 1990; Biquand and Biquand-Guyot 1992; Provenza and Cincotta 1993; Howery et al. 1996, 1998). Naive animals foraging with social models generally spend less time foraging and exploring their environment but ingest more forage, suffer less from predation and malnutrition, and ingest fewer toxic plants than naive animals foraging alone (Provenza and Cincotta 1993). Social learning theory suggests that the most important 
models for a young animal are its mother and young companions (Bandura 1977). Learning from mother, peers, or other social models may also be important when rapid changes in foraging environments (e.g., drought, fire, invasion of another herbivore species) alter forage and habitat availability (Key and MacIver 1980; Collins and Urness 1983). Both domestic and wild ungulates have exhibited predictable distribution patterns from year to year that are presumably influenced by mother or peers (Gruell and Papez 1963; Festa-Bianchet 1986, 1988; Cederlund et al. 1987).

Mother markedly influences the establishment (Key and MacIver 1980; Lynch et al. 1983; Mirza and Provenza 1990, 1991; Thorhallsdottir et al. 1990) and persistence (Green et al. 1984; Lynch 1987; Nolte et al. 1990; Thorhallsdottir et al. 1990) of her offspring's diet and habitat selection behavior. However, as animals mature, they depend less on mother for milk and mother's influence wanes (Hinch et al. 1987; Mirza and Provenza 1990, 1991), and young companions can markedly influence one another's diet and habitat-selection patterns. For instance, lambs that were averted to the shrub mountain mahogany (Cercocarpus montanus Raf.) by pairing its ingestion with lithium chloride $(\mathrm{LiCl})$ consumed more mountain mahogany when they foraged with nonaverted peers than when they foraged alone (Provenza and Burritt 1991). A group of heifers ( $B$. taurus) that were averted to subaplpine larkspur (Delphinium barbeyi [Huth] Huth) avoided the plant for 3 years until they were placed in a pasture with nonaverted peers, at which point they began eating larkspur at similar levels to the nonaverted heifers (Lane et al. 1990). Thus, diet and habitat selection activities of the herd strongly influence the actions of individuals.

Social models also affect habitat-selection decisions. Yearling heifers on a 1200 -ha summer range-grazing allotment in Idaho formed a subgroup that typically functioned independently of older cows and moved as a unit across the entire allotment, even though their previous exposure to the allotment with mother was restricted to 1 of 2 distinct home range areas that rarely overlapped (Howery et al. 1996). However, when drought restricted forage and water availability in subsequent years, habitat selection was influenced more by environmental conditions and/or by previous exposure with mother and less by peers (Howery et al. 1998). This suggests that social learning may help to introduce behavior(s) into an animal's repertoire, but the persistence of the behavior primarily depends on the consequences to the individual (Galef 1988).

Experiences of youth can shape diet and habitat preferences. Cross-fostering research with calves and lambs shows that where an animal is reared has a much greater influence on habitat selection than the genetic makeup of its natural or foster mother (Key and MacIver 1980; Howery et al. 1998). Offspring typically remain near where they were reared, unless lack of water and forage resources force them to move to new locations, and even then, animals are generally reluctant to leave familiar surroundings for long. After animals are weaned, experiences with peers affect distribution, but experiences early in life with mother have a more persistent influence on habitat and location preferences.

Although social learning is often cited as an adaptive mechanism that allows animals to transfer the location of desirable foods and habitats, social learning can occasionally be maladaptive. Sheep (Lynch 1974; Gluesing and Balph 1980;
El Aich and Rittenhouse 1988), cattle (Hodder and Low 1978), goats (Biquand and Biquand-Guyot 1992), deer (Gillingham and Bunnell 1989), and moose (Andersen 1991) walk long distances searching for preferred plants or habitats, often passing areas with abundant forage along the way. Geist (1977) suggested that bighorn sheep (Ovis canadensis) were unable to expand their established home ranges because young animals rigidly conformed to the habitat-use patterns of their predecessors. Archaeological evidence along migration routes revealed that moose (Alces alces) in Norway continued the same migration patterns for 5000 years despite deterioration of their range (Andersen 1991). Thus, tight cohesion among familiar herd members may constrict habitat-use patterns and keep individual animals from seeking or exploring new habitats.

From a management perspective, the degree to which social relationships are allowed to develop may affect the efficiency of information transfer. When social relationships of domestic ungulate herds are disrupted by management practices, animal behavior and performance usually suffer (Kilgour 1972; Lynch et al. 1992). For example, strangers introduced into an established goat herd caused its existing social structure to break down and agonistic behavior to increase for 4 weeks (Addison and Baker 1982). Howery and colleagues (1996, 1998) speculated that mixing strangers with familiar animals from one year to the next could have disrupted previously established social relationships within a cattle herd and altered individual home-range and habitat-use patterns in successive years on summer range in Idaho.

\section{UNDERSTANDING FORAGING BEHAVIOR TO MEET MANAGEMENT OBJECTIVES}

Foraging animals also have immense abilities to modify their behavior within their lifetimes to respond to challenges in the foraging environment (Provenza and Balph 1990). A basic understanding of how foraging behaviors are created and maintained can create opportunities to alter behavior patterns to meet the demands of animal and landscape management. Behaviors of free-ranging herbivores include foraging, drinking, ruminating/resting, and escaping from predators. Animals go through life responding to internal and external stimuli that direct behavior (Fig. 3). Animals engage in a contextually appropriate behavior (i.e., grazing or ruminating) until that behavior ceases to be reinforcing (Frieman 2002). This promotes a change in activity or movement to a new habitat. Movement into a specific habitat is directed by the perceived presence of food, water, appropriate temperature, safety, etc. (i.e., habitat attributes) or by previous access to food, water, etc. (i.e., memory). Responses are also strongly affected by the activities of peers in the herd or flock (i.e., social influences). Finally, the value of a specific habitat is continually reassessed based on current physiological state (i.e., motivation or internal stimuli). Rangeland managers have considerable opportunity to intervene in the ongoing expression of behavior and the processes that create habitat preferences and patterns of foraging herbivores.

Land-management efforts can be focused on changing the reinforcing properties of habitats and the cues animals associate with these consequences (i.e., altering habitat attributes; Fig. 3). 


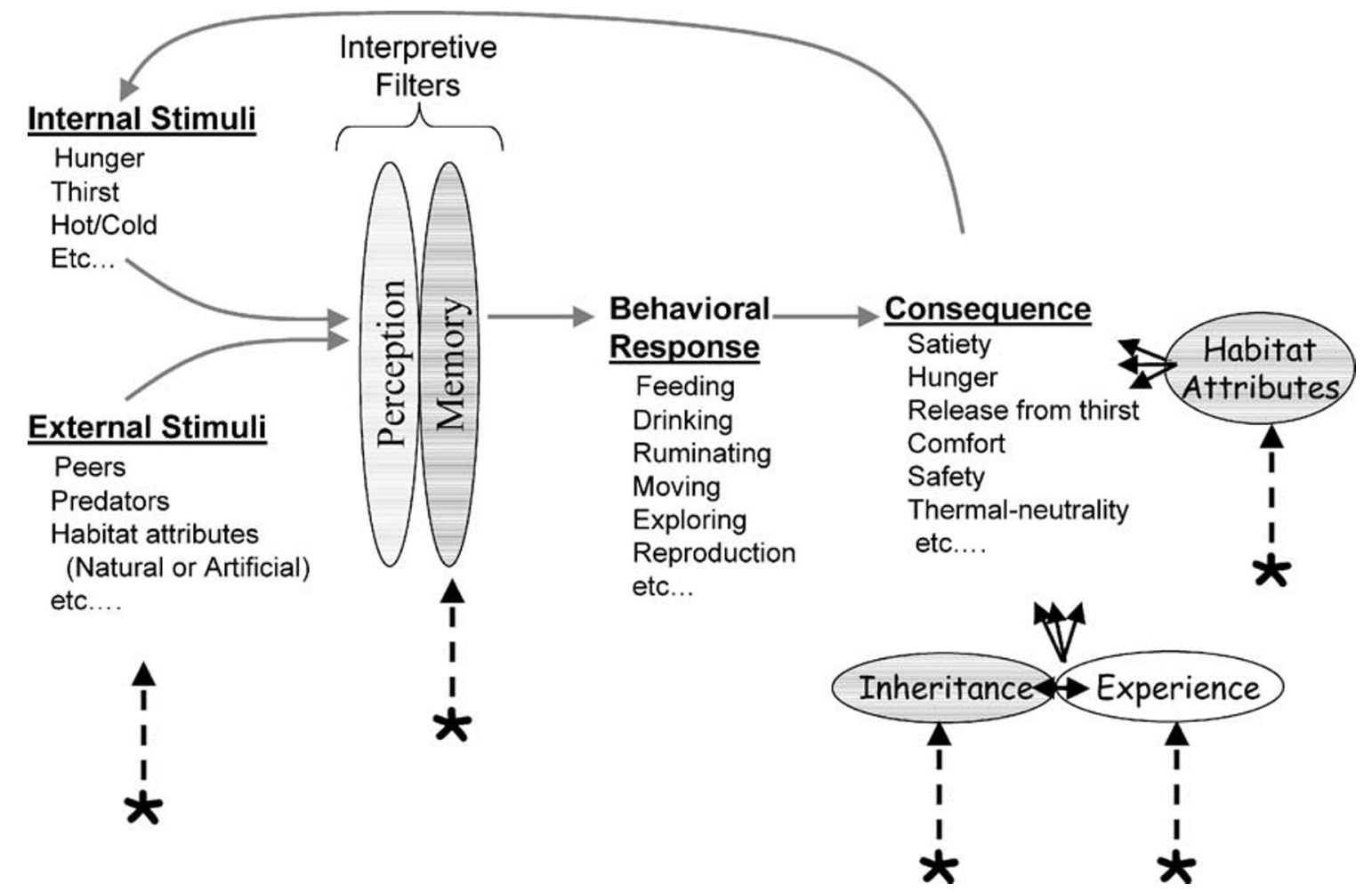

Figure 3. The observed behavior patterns of foraging animals are based on the consequences of behavior in specific habitats. These consequences are set by habitat characteristics and animal attributes. The inheritance and experience of an animal determines its physiological and morphological attributes that affect the consequences of residing in a specific habitat. Arrows indicate components that could be altered with management inputs.

It is well known that habitat distribution patterns can be altered by fertilizing, burning, planting, or otherwise changing the forage value of a piece of rangeland (Valentine 1990). The widely practiced installation of water sources to change livestock distribution is an example of altering habitat attributes. Managers have also attempted to alter animal distribution in a pasture or allotment by placing rewards, such as molasses supplement (Bailey and Welling 1999) or salt (Martin and Ward 1973; Bailey and Welling 1999; DelCurto et al. 1999), in locations where greater utilization is desired. Installing artificial shade has also been suggested as a way to change the thermal attributes of an area to increase its use by livestock (DelCurto et al. 1999). These landscape interventions alter the consequences that animals experience when foraging in these habitats. This manipulation can alter livestock preference for specific areas and change habitat-use patterns.

Land managers may also be able to use sensory cues (external stimuli; Fig. 3) to help animals find and remember the location of habitat resources and thereby alter distribution patterns. Research by Howery et al. (2000) and Bailey and Welling (1999) suggests that artificial visual cues could be used to alter animal distribution on rangelands. Cattle could be trained to recognize specific items (e.g., flags, posts, or pylons) associated with food or supplement to lure them to underutilized rangeland areas. For example, a rancher in Idaho has used wind chimes (i.e., an audio cue) to inform cattle about the location of salt/mineral supplements and draw them to these areas (J. Dyer, personal communication). The careful use of visual and audio cues associated with supplements or other rewards could become tools to encourage livestock movement to specific areas.
The rewarding or aversive consequences experienced by foraging animals is certainly determined by land attributes but can also be influenced by the animal's morphology and physiology. Specific management strategies could be directed at altering animal attributes by managing the inheritance or experience of a herd or flock (Fig. 3). Breeds of livestock differ in their diet preferences (Launchbaugh et al. 1999) and use of foraging areas of varying slope, roughness, or distances from water (Herbel and Nelson 1966; Winder et al. 1996; Bailey et al. 2001). Managers could select and breed animals with the desired diet or habitat-use characteristics to meet specific ecological livestock-production goals. For example, breeds developed in mountainous regions, such as Tarentaise, apparently possess superior landscape use skills (Bailey et al. 2001). Therefore, improved livestock distribution in pastures with steep, rough topography might be obtained by altering the livestock-breeding program.

We also know that age and physiological state affect what and where an animal grazes. Apparently, landscape-use patterns could be managed by selecting young animals that range widely and readily explore new habitats (Dunn et al. 1988; Howery et al. 1996). However, mature animals familiar with the landscape may have superior abilities to exploit resources that could have favorable livestock-production outcomes, but grazing with mature animals may or may not lead to improved distribution patterns (Bryant 1982; Beaver and Olson 1997).

A skilled livestock manager may even be able to create training regimes for livestock to more effectively use pasture resources. Prescribed experiences might include training on rough terrain early in life to acquire necessary physical skills. It is likely 
that animals could be trained to seek forage resources greater distances from water. Therefore, humans have considerable opportunity to direct the experience and interactions between livestock and land. These suggested management practices are quite speculative, but undoubtedly possible.

\section{CONCLUSIONS}

Rangeland management studies in animal behavior are typically snapshots in time that document how current environmental conditions and contingencies influence animal behavior at a particular place and time. Although snapshots have considerable value in describing the animal behavior for ad hoc conditions, they ignore the conditions and events that shaped the animal's behavior at the time of study and the snapshot was taken. The principles we have outlined constitute a theoretical framework from which new research questions and management practices can be posed and tested. Such questions should lead to new ways to explore and discover how ultimate and proximate consequences influence the behavior we observe today and accordingly improve our ability to predict and manage how animals will behave in the future. As B. F. Skinner said, "The probability that an organism will behave in a given way is a more valuable datum than the mere fact that it does so behave" (Skinner 1966).

\section{LITERATURE CITED}

Addison, W. E., and E. Baker. 1982. Agonistic behavior and social organization in a herd of goats as affected by the introduction of non-members. Applied Animal Ethology 8:527-535.

ANDERSEN, R. 1991. Habitat deterioration and the migratory behaviour of moose (Alces alces L.) in Norway Journal of Applied Ecology 28:102-108.

AndeRSon, D. M. 2001. Virtual fencing-a prescription range animal management tool for the 21st century. A. M. Sibbald and I. J. Gordon [eds.]. Proceedings of the Conference on Tracking Animals with GPS. Aberdeen, Scotland: The Macaulay Institute. p 85-94.

Balley, D. W. 1995. Daily selection of feeding areas by cattle in homogeneous and heterogeneous environments. Applied Animal Behavior Science 45:183-199.

Bailey, D. W., J. E. Gross, E. A. Laca, L. R. Rittenhouse, M. B. Coughenhour, D. M. SWIFT, AND P. L. SIMS. 1996. Mechanisms that result in large herbivore grazing distribution patterns. Journal of Range Management 49:386-400.

Balley, B. W., D. D. Kress, D. C. Anderson, D. L. Boss, and E. T. Miller. 2001. Relationship between terrain use and performance of beef cows grazing foothill rangeland. Journal of Animal Science 76:1883-1891.

Bailey, D. W., L. R. Rittenhouse, R. H. Hart, D. M. Swift, and R. W. Richards. 1989. Association of relative food availabilities and locations by cattle. Journal of Range Management 42:480-482.

Balley, D W., AND P. L. Sims. 1998. Association of food quality and locations by cattle. Journal of Range Management 51:2-8.

Balley, D. W., AND G. R. Welling. 1999. Modification of cattle grazing distribution with dehydrated molasses supplement. Journal of Range Management 52 575-582.

Bandura, A. 1977. Social learning theory. Englewood Cliffs, NJ: Prentice-Hall.

Bazely, D. R., AND C. V. Ensor. 1989. Discrimination learning in sheep with cues varying in brightness and hue. Applied Animal Behavior Science 23:293-299.

BeAver, J. M., AND B. E. OLSON. 1997. Winter range use by cattle of different ages in southwestern Montana. Applied Animal Behavior Science 51:1-13.

Biquand, S., and V. Biquand-GuYot. 1992. The influence of peers, lineage and environment on food selection of the criollo goat (Capra hircus). Applied Animal Behavior Science 34:231-245.

Boıssy, A. 1998. Fear and fearfulness in determining behavior. In: T. Grandin [ed.].
Genetics and the behavior of domestic animals. New York, NY: Academic Press. p 67-111.

BRyant, L. D. 1982. Response of livestock to riparian zone exclusion. Journal of Range Management 35:780-785.

Budd, B. 1999. Livestock, wildlife, plants and landscapes: putting it all together. In: K. L Launchbaugh, K. D. Sanders, and J. C. Mosley. Grazing behavior of livestock and wildlife. Moscow, ID: University of Idaho. Idaho Forest, Wildlife, and Range Experiment Station Bulletin No. 70. p 137-142. Available at: http:// www.cnr.uidaho.edu/range/publications/. Accessed 15 February 2005.

Burritt, E. A., and F. D. Provenza. 1997. Effect of an unfamiliar location on the consumption of novel and familiar foods by sheep. Applied Animal Behavior Science 54:317-325.

Carr, G. D., H. C. Fiberger, and A. G. Phillips. 1989. Conditioned place preference as a measure of drug reward. In: J. M. Libman, and S. J. Cooper. [eds.]. The neuropharmacological basis of reward. Oxford, England: Clarendon Press, Oxford University Press. p 264-317.

Cederlund, G., F. Sandegren, and K. Larsson. 1987. Summer movements of female moose and dispersal of their offspring. Journal of Wildlife Management $51: 342-352$

Cibils, A. F., L. D. Howery, and G. B. Ruyle. 2004. Diet and habitat selection by cattle: the relationship between skin- and gut-defense systems. Applied Animal Behavior Science 88:187-208.

Collins, W. B., And P. J. URness. 1983. Feeding behavior and habitat selection of mule deer and elk on northern Utah summer range. Journal of Wildlife Management 47:646-663.

Coughenour, M. B. 1991. Spatial components of plant-herbivore interactions in pastoral, ranching, and native ungulate ecosystems. Journal of Range Management 44:530-543.

DelCurto, T., M. Porath, M. Mclnnins, P. Momont, and C. Parsons. 1999. Management strategies for optimal beef cattle distribution and use of mountain riparian meadows. In: K. L. Launchbaugh, K. D. Sanders, and J. C. Mosley [eds.]. Grazing behavior of livestock and wildlife. Moscow, ID: University of Idaho. Idaho Forest, Wildlife, and Range Experiment Station Bulletin No. 70. p. 119-129. Available at: http://www.cnr.uidaho.edu/range/ publications/. Accessed 15 February 2005.

Distel, R. A., And F. D. Provenza. 1991. Experience early in life affects voluntary intake of blackbrush by goats. Journal of Chemical Ecology 17:431-450.

Dudzinski, M. L., W. J. MulleR, W. A. Low, And H. J. Schun. 1982. Relationship between dispersion behaviour of free-ranging cattle and forage conditions. Applied Animal Ethology 8:225-241.

Dudzinski, M. L., H. J. Schuh, D. G. Wilcox, H. G. Gardiner, and J. G. Morrisey. 1978. Statistical and probabilistic estimators of forage conditions from grazing behaviour of merino sheep in a semi-arid environment. Applied Animal Ethology 4:357-368.

Dunn, R. W., K. M. Havstad, and E. L. Ayers. 1988. Grazing behavior response of rangeland beef cattle to winter ambient temperature and age. Applied Animal Behavior Science 21:201-207.

Edwards, G. R., J. A. Newman, A. J. Parsons, and J. R. Krebs. 1997. Use of cues by grazing animals to locate food patches: an example in sheep. Applied Animal Behavior Science 51:59-68.

El Aich, A., AND L. R. RitTenhouse. 1988. Use of habitats by free-grazing sheep. Applied Animal Behavior Science 21:223-231.

EPLEY, S. 1974. Reduction of the behavioral effect of aversive stimulation by the presense of companions. Psychology Bulletin 81:271-283.

FAy, P. K., V. T. McElligotT, AND K. M. HavStad. 1989. Containment of free-ranging goats using pulsed-radiowave-activated shock. Applied Animal Behavior Science 23:165-171.

Festa-BianChet, M. 1986. Seasonal dispersion of overlapping mountain sheep ewe groups. Journal of Wildlife Management 50:325-330.

Festa-Bianchet, M. 1988. Seasonal range selection in bighorn sheep: conflicts between forage quality, forage quantity, and predator avoidance. Oecologia $75: 580-586$.

Frieman, J. 2002. Learning and adaptive behavior. Belmont, CA: Wadsworth Group.

GALEF, B. G., JR., 1988. Imitation in animals: history, definition, and interpretation of data from the psychological laboratory. In: T. R. Zentall and B G. Galef, Jr. 
[eds.]. Social learning: Psychological and biological perspectives. Hillsdale, NJ: Lawrence Erlbaum Associates. p. 3-28.

Garcia, J., AND M. D. Holder. 1985. Time, space and value. Human Neurobiology 4:81-89.

Garcia, J., and R. A. Koelling. 1966. Relation of cue to consequence in avoidance learning. Psychonomic Science 4:12-124.

Garcia, J., P. A. Lasiter, F. Bermudez-Rattoni, and D. A. Deems. 1985. A general theory of aversion learning. In: N. S. Braveman and P. Bronstein [eds.]. Experimental assessments and clinical applications of conditioned food aversions. New York, NY: New York Academy of Science. p 8-21.

GeIst, V. 1977. A consequence of togetherness, p. 447-452. In: T.E. McGill [ed.]. Readings in animal behavior. 3rd ed. New York, NY: Rinehard and Winston.

Giluingham, M. P., And F. L. Bunnelt. 1989. Effects of learning on food selection and searching behavior of deer. Canadian Journal of Zoology 67:24-32.

Gluesing, E. A., AND D. F. Balph. 1980. An aspect of feeding behavior and its importance to grazing systems. Journal of Range Management 33:426-427.

Grandin, T., And M. J. Deesing. 1998. Genetics and behavior during handling, restraint, and herding. In: T. Grandin [ed.]. Genetics and the behavior of domestic animals. New York, NY: Academic Press. p 113-144.

Green, G. C., R. L. Elwin, B. E. Mottershead, and J. J. Lynch. 1984. Long-term effects of early experience to supplementary feeding in sheep. Proceedings of the Australian Society of Animal Production 15:373-375.

Gruell, G. E., and N. J. Papez. 1963. Movements of mule deer in northeastern Nevada. Journal of Wildlife Management 27:414-422.

HAfEz, E. S. E. 1969. Behaviour of domestic animals. London, England: Bailliere, Tindall, and Cassell.

Herbel, C. H., and A. B. Nelson. 1966. Activities of Hereford and Santa Gertrudis cattle on the southern New Mexico range. Journal of Range Management 19:173-181.

Hinch, G. N., E. Lecrivain, J. J. Lynch, And R. L. Elwin. 1987. Changes in maternal young associations with increasing age of lambs. Applied Animal Behavior Science 17:305-318.

Hodder, R. M., AND W. A. Low. 1978. Grazing distribution of free-ranging cattle at three sites in the Alice Springs District, central Australia. Australian Rangeland Journal 1:95-105.

Hofmann, R. R. 1989. Evolutionary steps of ecophysiological adaptation and diversification of ruminants: a comparative view of their digestive system. Oecologia 78:443-457.

Howery, L. D., D. W. Bailey, G. B. Ruyle, and W. J. Renken. 2000. Cattle use visual cues to track food locations. Applied Animal Behavior Science 67:1-14.

Howery, L. D., F. D. Provenza, R. E. Banner, and C. B. Scott. 1996. Differences in home range and habitat use among individuals in a cattle herd. Applied Animal Behavior Science 49:305-320.

Howery, L. D., F. D. Provenza, R. E. Banner, and C. B. Scott. 1998. Social and environmental factors influence cattle distribution on rangeland. Applied Animal Behavior Science 55:231-244.

Hutson, G. D. 1981. Food preferences of sheep. Australian Journal of Experimental Agricultural Animal Husbandry 21:575-580.

Illius, A. W., AND I. J. GoRdon. 1993. Diet selection in mammalian herbivores: constraints and tactics. In: R. N. Hughes [ed.]. An interdisciplinary approach to foraging behavior. Boston, MA: Blackwell Scientific Publishing. p 157-181.

Jones, A. 2000. Effects of cattle grazing on North American arid ecosystems: a quantitative review. Western North American Naturalist 60:155-164.

Key, C., AND R. M. Maclver. 1980. The effects of maternal influences on sheep: breed differences in grazing, resting and courtship behavior. Applied Animal Ethology 6:33-48.

KILgouR, R. 1972. Animal behaviour in intensive systems and its relationship to disease and production. Australian Veterinary Journal 48:94-98.

LACA, E. A. 1998. Spatial memory and food searching mechanisms of cattle. Journal of Range Management 51:370-378.

Lane, M. A., M. H. Ralphs, J. D. Olsen, F. D. Provenza, and J. A. Pfister. 1990. Conditioned taste aversion: potential for reducing cattle loss to larkspur. Journal of Range Management 43:127-131.

Launchbaugh, K. L., and F. D. Provenza. 1993. Can plants practice mimicry to avoid grazing by mammalian herbivores? Oikos 66:501-504.
Launchbaugh, K. L., J. W. Walker, and C. A. Taylor. 1999. Foraging behavior: experience of inheritance? In: K. L. Launchbaugh, K. D. Sanders, and J. C. Mosley [eds.]. Grazing behavior of livestock and wildlife. Moscow, ID: University of Idaho. Idaho Forest, Wildlife, and Range Experiment Station Bulletin No. 70. p 28-35. Available at: http://www.cnr.uidaho.edu/range/ publications/. Accessed 15 February 2005.

LYNCH, J. J. 1974. Merino sheep: Some factors affecting their distribution in very large paddocks. In: V. Geist and F. Walther [eds.]. Behaviour of ungulates and its relation to management. Mores, Switzerland: International Union for Conservation of Nature. p 697-707.

LYNCH, J. J. 1987. The transmission from generation to generation in sheep of the learned behaviour for eating grain supplements. Australian Veterinary Journal 64:292-292.

Lynch, J. J., R. G. Keogh, R. L. Elwin, G. C. Green, and B. E. Mottershead. 1983. Effects of early experience on the post-weaning acceptance of whole grain wheat by fine-wool Merino lambs. Animal Production 36:175-183.

LYNCH, J. J., G. N. HINCH, AND D. B. AdAms. 1992. The behaviour of sheep: biological principles and implications for production. Wallingford, Oxon, England and East Melbourne, Australia: CAB International and CSIRO.

Martin, S. C., And D. E. WARD. 1973. Salt and meal-salt help distribute cattle use on semidesert range. Journal of Range Management 26:94-97.

McSweeney, F. K. 1999. Making sense of animal conditioning. In: K. L. Launchbaugh, K. D. Sanders, and J. C. Mosley [eds.]. Grazing behavior of livestock and wildlife. Moscow, ID: University of Idaho. Idaho Forest, Wildlife, and Range Experiment Station Bulletin No. 70. p 13-19. Available at: http:// www.cnr.uidaho.edu/range/publications/. Accessed 15 February 2005.

Mirza, S. N., And F. D. Provenza. 1990. Preference of the mother affects selection and avoidance of foods by lambs differing in age. Applied Animal Behavior Science 28:255-263.

Mirza, S. N., and F. D. Provenza. 1991. Socially induced food avoidance in lambs: direct or indirect maternal influence? Journal of Animal Science 72:899-902.

NoLte, D. L. 1999. Behavioral approaches for limiting depredation by wild ungulates. In: K. L. Launchbaugh, K. D. Sanders, and J. C. Mosley (eds.), Grazing behavior of livestock and wildlife. Moscow, ID: University of Idaho. Idaho Forest, Wildlife, and Range Experiment Station Bulletin No. 70. p 60-69. Available at: http://www.cnr.uidaho.edu/range/publications/. Accessed 15 February 2005.

Nolte, D. L., F. D. Provenza, and D. F. Balph. 1990. The establishment and persistence of food preferences in lambs exposed to selected foods. Journal of Animal Science 68:998-1002.

PARKER, L. A. 1992. Place conditioning in the three- or four-choice apparatus role: role of stimulus novelty in drug-induced place conditioning. Behavior Neuroscience 106:294-306.

Pavlov, I. P. 1927. Conditioned reflexes. London, England: Oxford University Press. $430 \mathrm{p}$.

PiePer, R. D. 1994. Ecological implications of livestock grazing. In: M. Vavra, W. A. Laycock, and R. D. Pieper [eds.]. Ecological implications of livestock herbivory. Denver, C0: Society of Range Management. p 176-211.

Provenza, F. D. 1995. Postingestive feedback as an elementary determinant of food preference and intake in ruminants. Journal of Range Management 48:2-17.

ProvenzA, F. D. 1996. Acquired aversions as the basis for varied diets of ruminants foraging on rangelands. Journal of Animal Science 74:2010-2020.

Provenza, F. D., And D. F. Balph. 1990. Applicability of five diet-selection models to various foraging challenges ruminants encounters. In: R. N. Hughes [ed.]. Behavioural mechanisms of food selection. NATO ASI Series G: Ecological Science. Volume 20. Berlin, Heidelberg, Germany: Springer-Verlag. p 423-459.

Provenza, F. D., And E. A. Burritt. 1991. Socially-induced diet preference ameliorates conditioned food aversion in lambs. Applied Animal Behavior Science 31:229-236.

Provenza, F. D., and R. P. Cincotta. 1993. Foraging as a self-organizing learning process: accepting adaptability at the expense of predictability. In: R. N. Hughes [ed.]. Diet selection: An interdisciplinary approach to foraging behavior. Boston, MA: Blackwell Scientific Publishing. p 78-101.

Provenza, F. D., and K. L. Launchbaugh. 1999. Foraging on the edge of chaos. In: K. 
L. Launchbaugh, K. D. Sanders, and J. C. Mosley [eds.]. Grazing behavior of livestock and wildlife. Moscow, ID: University of Idaho. Idaho Forest, Wildlife, and Range Experiment Station Bulletin No. 70. p 1-12. Available at: http:// www.cnr.uidaho.edu/range/publications/. Accessed 15 February 2005.

Provenza, F. D., J. A. Pfister, and C. D. Cheney. 1992. Mechanisms of learning in diet selection with reference to phytotoxicosis in herbivores. Journal of Range Management 45:36-45.

Quigley, T. M., H. R. Sanderson, A. R. Tiedemann, and M. L. Mclnnis. 1990. Livestock control with electrical and audio stimulation. Rangelands 12:152-155.

Schechter, M. D., and D. J. Calcagnetti. 1998. Continued trends in conditioned place preference literature from 1992 to 1996, inclusive with a cross-indexed bibliography. Neuroscience and Biobehavior Review. 22:827-846.

Senft, R. L., M. B. Coughenour, D. W. Bailey, L. R. Rittenhouse, O. E. Sala, and D. M. Swift. 1987. Large herbivore foraging and ecological hierarchies. BioScience 37:789-799.

SkInNER, B. F. 1938. The behavior of organisms. New York, NY: Apleton-CenturyCrofts. $457 p$.

SkINNER, B. F. 1966. The phylogeny and ontogeny of behavior. Science 11:159-166.

Thorhallsdottir, A. G., F. D. Provenza, and D. F. Balph. 1990. Ability of lambs to learn about novel foods while observing or participating with social models. Applied Animal Behavior Science 25:25-33.

TZSCHENTKE, T. M. 1998. Measuring reward with the conditioned place preference paradigm: a comprehensive review of drug effects, recent progress, and new issues. Progress in Neurobiology 56:613-672.

Valentine, J. F. 1990. Grazing management. San Diego, CA: Academic Press.

Vandenheede, M., And M. F. Boulssou. 1994. Fear reaction of ewes to photographic images. Behavioural Processes 32:17-28.

Veissier, I., AND P. Le Neindre. 1992. Reactivity of aubrac heifers exposed to a novel environment alone or in groups of four. Applied Animal Behavior Science 33:11-15.

WALKER, J. W. 1995. Viewpoint: grazing management and research now and in the next millennium. Journal of Range Management 48:350-357.

WeCKER, S. C. 1963. The role of early experience in habitat selection by the prairie deer mouse, Peromyscus maniculatus bairid. Ecological Monographs 4: 307-325.

Winder, J. A., D. A. Walker, and C. C. Balley. 1996. Effect of breed on botanical composition of cattle diets on Chihuahuan desert range. Journal of Range Management 49:209-214. 